\title{
FEATURES OF SYPHILITIC INFECTION IN CHERNIVTSI REGION RESIDENTS
}

\author{
M.Yu.Gaievska, Yu.Ya.Vasylevych, K.H.Pankiv, Yu.V.Sofroni
}

Higher State Educational Establishment of Ukraine "Bukovinian State Medical University"

Key words: syphilitic infection, clinical manifestations, serological reactions.

Clinical and experimental pathology. Vol.17, №1 (63). P.31-34.

DOI:10.24061/17274338.XVII.1.63.2018.73

E-mail: if_dermven (a)ukr.net
Abstract. Syphilis is one of the most significant social diseases. It is important to study the clinical and serological features of syphilis in order to timely diagnose and effectively treat it. The purpose of the study is to establish the clinical and serological features of syphilitic infection in the inhabitants of the Chernivtsi region. A retrospective analysis of this disease history in the patients with syphilis living in Chernivtsi region for 2012-2017 has been conducted. The features of the clinical picture and the results of serological reactions to syphilis have been studied. It was found that patients with a primary period of syphilis are characterized by the predominance of the ulcerous form of the hard chancre with the development of complications and moderate inguinal scleradenitis; secondary fresh syphilis is characterized by the presence of specific quinsy, polyadenitis and moderate roseola, localization of papules on the mucous membranes of the genital organs, and in secondary recurrent syphilis the papules are on the mucous membranes of the mouth, on genitals, palms and soles, there is moderate polyadenitis as well as signs of specific sore throat and syphilitic leukoderma.

\section{ОСОБЕННОСТИ СИФИЛИТИЧЕСКОЙ ИНФЕКЦИИ У ЖИТЕЛЕЙ ЧЕРНОВИЦКОЙ ОБЛАСТИ}

сифилитическая

инфекция,

клинические

проявления,

серологические

реакции.

\section{М.Ю. Гаевская, Ю.Я. Василевич, К.Г. Панькив, Ю.В. Софрони}

Резюме. Сифилис является одним из значимых заболеваний сочиального характера. Важным остается изучение клинических и серологических особенностей сифилиса для своевременной диагностики и эффективного лечения. Цель исследования - установить клинико-серологические особенности сифилитической инфекции у жителей Черновичкой области. Проведен ретроспективный анализ историй болезней пачиентов, больных сифилисом, которые проживают в Черновичкой области, за 2012-2017 годы. Изучали особенности клинической картины и результаты серологических реакций на сифилис. Установлено, что у больных на первичный период сифилиса клинически характерно преобладание язвенной формы твердого шанкра с развитием осложнений и умеренный паховый склераденит; для вторичного свежего сифилиса характерно наличие спечифической ангины, полиаденита и умеренной розеолы, локализачия папул на слизистых оболочках половых органов, а для вторичного рецидивного сифилиса - папулы на слизистых оболочках рта, на гениталиях, ладонях и подошвах, умеренный полиаденит, а также признаки специфической ангины и сифилитической лейкодермы.

Ключові слова:
сифілітична
інфекція, клінічні
прояви,
серологічні
реакцї.
Клінічна та
експериментальна
патологія Т.17, №1
(63). С.31-34.

\section{ОСОБЛИВОСТІ СИФІЛІТИЧНОЇ ІНФЕКЦЇ У МЕШКАНЦІВ ЧЕРНІВЕЦЬКОЇ ОБЛАСТІ}

\section{М.Ю. Гаєвська, Ю.Я. Василевич, К.Г. Паньків, Ю.В. Софроні}

Резюме. Сифіліс є одним із значимих захворювань сочіального характеру. Важливим залишається вивчення клінічних і серологічних особливостей сифілісу задля своєчасної діагностики і ефективного його лікування. Мета дослідження - встановити клініко-серологічні особливості сифілітичної інфекції у жителів Чернівечькоӥ області. Проведено ретроспективний аналіз історій хвороб пачієнтів, хворих на сифіліс, які проживають у Чернівечькій області, за 2012-2017 роки. Вивчали особливості клінічної картини та результати серологічних реакцій на сифіліс. 3'ясовано, що у хворих на первинний період сифілісу клінічно характерне переважання виразкової форми твердого шанкру з розвитком ускладнень та помірний пахвинний склераденіт; для вторинного свіжого сифілісу характерна наявність спечифічної ангіни, поліаденіту та помірної розеоли, локалізачія папул на слизових оболонках статевих органів, а для вторинного рецидивного сифілісу - папули на слизових оболонках рота, на геніталіях, долонях і підомвах, помірний поліаденіт, а також ознаки спечифічної ангіни та сифілітичної лейкодерми. 


\section{Introduction}

Despite modern methods of diagnosis, improvement of treatment regimens, using informative and preventive measures in the population of reproductive age, syphilitic infection remains a topical medical and social problem in Ukraine and in the Chernivtsi region in particular [3, 4, 8]. Western European countries, where every year 5.6 million people are diagnosed with syphilis, [ 6]. are not an exception. The incidence of this disease is caused by the migration processes of the population, neglect of the traditional norms of morality and behavior, the spread of prostitution among young people, a dismissive attitude to the risk of sexually transmitted diseases in casual sexual contacts. [1]. Syphilis at the present stage is characterized by an extension of the incubation period and the prevalence of latent and recurrent forms [5]. Syphilitic infection has typical clinical manifestations on the skin and mucous membranes and can also cause damage to the internal organs, the nervous and cardiovascular systems. There is an intrauterine infection of the fetus, an increase in the incidence of congenital syphilis [5, 7]. It should be noted that syphilis negatively affects the quality of life. Physical aspect of health is affected in patients with the primary form of syphilis while in the case of secondary syphilis, patients notice changes in their emotional state [2].

\section{Objective}

To establish clinical and serological features of syphilitic infection among the residents of Chernivtsi region.

\section{Materials and methods}

A retrospective analysis of the statistical data involved 715 patients with syphilis who were treated at the CMI "Chernivtsi Regional Dermatovenerologic Dispensary" in 2012-2017. During the analysis, the patients' complaints, the data of anamnesis of life and disease, objective examination, the results of classical serological syphilis responses (CSR) containing the microprecipitation reaction with the cardiolipin antigen and that of binding the complement to the treponemal and cardiolipin antigens according to unified methods were taken into consideration. All studies were conducted in accordance with the Order of the Ministry of Health of Ukraine No. 997 of November 22, 2013 "On Approval of Methodological Recommendations" Modern Approaches to Laboratory Diagnosis of Syphilis ".

\section{Results and discussion}

715 histories of patients with early forms of syphilitic infection have been analyzed. Primary syphilis (Lues I) was diagnosed in 38 (11.9\%) people, of whom in 9 individuals it was seronegative and in 29 - seropositive one. The diagnosis of secondary syphilis (Lues II recens) was made in $89(28.5 \%)$ patients and secondary recurrent syphilis (Lues II recidiva) in $69(22.1 \%)$ individuals. Early latent syphilis was found in $136(37.5 \%)$ patients. Table 1 shows the clinical manifestations of primary syphilis. Analyzing the figures of Table 1, one can observe the predominance of ulcerous hard chancre (twice) over the erosive one. Primary syphilloma is mostly found on the genitals $(82.8 \%)$, but $6(17.2 \%)$ of them noted extra-genital

Table 1

Clinical manifestations of primary syphilis in patients of Chernivtsi region

\begin{tabular}{|l|c|c|}
\hline \multirow{2}{*}{ Clinical manifestations } & \multicolumn{2}{|c|}{ Number of patients } \\
\cline { 2 - 3 } & absolute figures $\mathbf{( n = 3 4 )}$ & relative figures (\%) \\
\hline Hard chancre:-erosive & 12 & 35,9 \\
ulcerative & 22 & 64,1 \\
\hline Hard chancre: - genital, & 28 & 82,8 \\
- extragenital & 6 & 17,2 \\
\hline Complication of hard chancre, incl .: & 9 & 27,2 \\
- balanoposthitis & 7 & 20,9 \\
- phimosis & 2 & 5,4 \\
\hline Regional scleradenitis: & 29 & \\
- inguinal & 3 & 85,1 \\
- submandibular & 2 & 9,9 \\
- not marked & & 5,0 \\
\hline
\end{tabular}

placement, in particular, in the mouth or around the anus. Complications of a hard chancre (balanoposthitis, phimosis) developed in $9(27.2 \%)$ patients with primary syphilis. The regional inguinal was detected in $29(85.1 \%)$ persons, the submandibular one - in $3(9.9 \%)$ individuals. The patients with secondary fresh syphilis (Table 2)

had moderate typhoid maculopapular rash, localized mainly on the lateral areas of the trunk and upper extremities. Manifestations of specific quinsy were observed in $66.3 \%$ of people. Papular rash was only manifested in $23.6 \%$ of patients with predominant placement on the skin of the genital organs $(13.5 \%)$. The remains of hard chancreis were present in $58(65.2 \%)$

ISSN 1727-4338 https://www.bsmu.edu.ua people, regional scleradenitis was observed in all patients and was moderate or insignificant.

The patients with Lues II recidiva tended to have popular rash- in $61(88,4 \%)$ individuals, which was mostly localized on the skin of the genitalia in the form of erosive papules. "Horny" papules were recorded on the palms and soles in $45(65.2 \%)$ patients, flat condylomae - in 13 (18.8\%) patients, seborrheic papules in $8(11.6 \%)$ patients. Papules on the trunk were observed in $11(15.9 \%)$ people. 31 (44.9\%) patients with Lues II recidiva, had typhoid maculopapular rash which is typical of this period. It should be noted that $23(33.3 \%)$ patients with secondary recurrent syphilis also had papules on the mucous 
Table 2

Description of clinical manifestations of secondary fresh and secondary recurrent syphilis in patients of Chernivtsi region

\begin{tabular}{|c|c|c|c|}
\hline \multirow[b]{2}{*}{ Syphilis stages } & \multirow[b]{2}{*}{ Clinical manifestations } & \multicolumn{2}{|c|}{ Number of patients } \\
\hline & & $\begin{array}{c}\text { Absolute figures } \\
\text { (n) }\end{array}$ & Relative figures, $\%$ \\
\hline \multirow[t]{5}{*}{ Lues II recens $(\mathrm{n}=89)$} & Typhoid maculopapular rash & 89 & 100,0 \\
\hline & $\begin{array}{l}\text { Papular rash, incl: } \\
\text { - papules on the genitals; } \\
\text { - papules on the trunk; } \\
\text { - papules in the oral mucous } \\
\text { membrane. }\end{array}$ & $\begin{array}{c}21 \\
12 \\
7 \\
5\end{array}$ & $\begin{array}{c}23,6 \\
13,5 \\
7,9 \\
5,6\end{array}$ \\
\hline & Specific quinsy & 59 & 66,3 \\
\hline & Remains of the hard chancre & 58 & 65,2 \\
\hline & Polyadenitis & 89 & 100,0 \\
\hline \multirow[t]{7}{*}{ Lues II recidiva $(\mathrm{n}=69)$} & Typhoid maculopapular rash & 31 & 44,9 \\
\hline & $\begin{array}{l}\text { Papular rash, incl: } \\
\text { - papules on the genitals; } \\
\text { - «horny» papules on the palms and } \\
\text { on the soles; } \\
\text { - papules in the oral mucous } \\
\text { membrane; } \\
\text { - flat condylomae; } \\
\text { - papules on the trunk; seborrheic } \\
\text { papules. }\end{array}$ & $\begin{array}{l}61 \\
46 \\
45 \\
23 \\
13 \\
11 \\
8 \\
\end{array}$ & $\begin{array}{l}88,4 \\
66,6 \\
65,2 \\
33,3 \\
18,8 \\
15,9 \\
11,6 \\
\end{array}$ \\
\hline & Pustular rash & 16 & 23,2 \\
\hline & Specific quinsy & 62 & 89,8 \\
\hline & Polyadenitis & 56 & 81,2 \\
\hline & Alopecia & 15 & 21,7 \\
\hline & Leucoderma & 4 & 5,8 \\
\hline
\end{tabular}

membrane of the mouth. At the same time, almost all patients $(89.8 \%)$ had manifestations of specific quinsy, $23.2 \%$ of patients noted a specific pustular skin rash. Syphilitic alopecia was registered in $15(21.7 \%)$ people, syphilitic leukoderma in the form of "Venus beads" - in 4 $(5.8 \%)$ patients. Polyadenitis was noted in all $(100.0 \%)$ patients with Lues II recens and in $56(81.2 \%)$ patients with secondary recurrent syphilis, which was only pronounced in $22(31.9 \%)$ patients. The analysis of serological reactions to syphilis revealed that 54 (17.4\%) patients with early (primary and secondary) forms of syphilis had positive CSR with high (1: 80-1: 160) titers of reagents, $210(67.1 \%)$ of patients had positive $(4+, 3+)$ CSR with low (1: 5-1:10) and average (1: 40-1:60) titers of reagents, in $49(15.5 \%)$ persons the $(2+)$ CSR were poorly positive.

\section{Conclusions}

Primary syphilis patients living in Chernivtsi region tended to have ulcerative forms of hard chancre with the development of complications of primary syphilloma and moderate inguinal scleradenitis. Secondary fresh syphilis is characterized by specific angina, polyadenitis and moderate roseola, localization of papules on the genital mucous membranes. In patients with secondary recurrent syphilis, papules were found on the mucous membranes of the mouth, on genitals, palms and soles, manifestations of syphilitic alopecia, moderate polyadenitis, as well as signs of specific quinsy and syphilitic leukoderma. Most of the patients in the early (primary and secondary) forms of syphilis had positive classical serological responses to syphilis with low (1: 5-1: 10) and average (1: 40-1: 60) titers of reagents.

\section{Prospects of further research}

The prospect of further research is an analysis of the effectiveness of modern methods and means of treatment and prevention of syphilis in patients living in the Chernivtsi region.

\section{Список літератури}

1.Андреев CВ, Сетко НП, Воронина ЛН. Оценка качества жизни больных сифилисом. Практическая медицина. 2014; 7:111-4.

2.Бондаренко ГМ, Нікітенко IM, Мужичук ВB, Безрученко OA, Сендецька ВВ, Зюбан IB. Епідеміологічні особливості сучасного сифілісу. Дерматологія та венерологія. 2016;3:92.

3.Бондаренко ГМ, Унучко СВ, Губенко ТВ, Матюшенко ВП. Клініко-епідеміологічні особливості сифілісу на сучасному етапі. Дерматологія та венерологія. 2014;2:65-70.

4. Денисенко ОI, Гаєвська МЮ, Перепічка МП. Клініко-серологічні особливості сифілітичної інфекції у жителів Чернівецької області. Клінічна та експериментальна патологія. 2015; 14(2):81-4.

5.Короленко ВВ. Аналіз епідеміологічної ситуації щодо сифілісу в країнах Європейського союзу та Сполучених Штатах Америки як передумова створення системи державного управління соціально небезпечними інфекціями. Український журнал дерматології, венерології, косметології. 2016;2:98-104.

6. Літус ОІ, Кутова ВВ, Білоконь ОМ, Бондаренко ГМ, Мавров ГІ, Щербакова ЮВ. Сучасні можливості серологічної діагностики сифілісу (порівняльний аналіз). Дерматологія та венерологія. 2013;4:34-43.

7.Слабкий ГО, Дерев'янко ЛА. Глобальна елімінація вродженого сифілісу: нові виклики для України. Вісник соціальної гігісни та організації охорони здоров'я України. 2013;1:5-10.

8.Радионов ВГ, Радионов ДВ, Хайминов ЕМ, Приходько ISSN 1727-4338 https://ww.bsmu.edu.ua 
ИА. Анализ эпидемиологической ситуации по заболеваемости сифилисом в Луганской области. Двадцать лет спустя. Актуальная инфектология. 2016;1:23-8.

\section{References}

1.Andreev SV, Setko NP, Voronina LN. Otsenka kachestva zhizni bol'nykh sifilisom [Assessment of the quality of life of patients with syphilis]. Prakticheskaya meditsina. 2014;7:111-4. (in Russian)

2.Denysenko OI, Haievs'ka MIu, Perepichka MP. Klinikoserolohichni osoblyvosti syfilitychnoi infektsii $u$ zhyteliv Chernivets'koi oblasti [Clinical and serological peculiarities of syphilitic infection in the residents of the Chernivtsi region] Klinichna ta eksperymental'na patolohiia. 2015;14(2):81-4. (in Ukrainian)

3.Bondarenko HM, Nikitenko IM, Muzhychuk VV, Bezruchenko OA, Sendets'ka VV, Ziuban IV. Epidemiolohichni osoblyvosti suchasnoho syfilisu [Clinical and epidemiologycal features of syphilis on the modern stage]. Dermatolohiia ta venerolohiia. 2016;3:92. (in Ukrainian)

4.Bondarenko HM, Unuchko SV, Hubenko TV, Matiushenko VP. Kliniko-epidemiolohichni osoblyvosti syfilisu na suchasnomu etapi [Clinical and epidemiological features of syphilis at the present stage]. Dermatolohiia ta venerolohiia. 2014;2:65-70. (in Ukrainian)

5.Korolenko VV. Analiz epidemiolohichnoi sytuatsii schodo syfilisu v krainakh Yevropeis'koho soiuzu ta Spoluchenykh Shtatakh Ameryky yak peredumova stvorennia systemy derzhavnoho upravlinnia sotsial'no nebezpechnymy infektsiiamy [Analysis of epidemiological situation of syphilis in the European Union and the United States as background of the public administration of socially dangerous infections]. Ukrains'kyi zhurnal dermatolohii, venerolohii, kosmetolohii. 2016;2:98-104. (in Ukrainian)

6.Litus OI, Kutova VV, Bilokon' OM, Bondarenko HM, Mavrov HI, Scherbakova YuV. Suchasni mozhlyvosti serolohichnoi diahnostyky syfilisu (porivnial'nyi analiz) [Modern possibilities of serological diagnostics of syphilis (the comparative analysis)]. Dermatolohiia ta venerolohiia. 2013;4:34-43. (in Ukrainian)

7.Slabkyi HO, Derev'ianko LA. Hlobal'na eliminatsiia vrodzhenoho syfilisu: novi vyklyky dlia Ukrainy [Global elimination of congenital syphilis: new challenges for Ukraine]. Visnyk sotsial'noi hihiieny ta orhanizatsii okhorony zdorov'ia Ukrainy. 2013;1:5-10. (in Ukrainian)

8.Radionov VG, Radionov DV, Khayminov EM, Prikhod'ko IA. Analiz epidemiologicheskoy situatsii po zabolevaemosti sifilisom v Luganskoy oblasti. Dvadtsat' let spustya [Analysis of the epidemiological situation on syphilis in Lugansk region. Twenty years later]. Aktual'naya infektologiya. 2016;1:23-8. (in Russian)

\section{Відомості про авторів:}

Гаєвська М.Ю. - к. мед. н., доцент кафедри дерматології та венерології Вищого державного навчального закладу України "Буковинський державний медичний університет", м. Чернівці

Василевич Ю.Я., лікар-інтерн дерматовенеролог Вищого державного навчального закладу України "Буковинський державний медичний університет", м. Чернівці

Паньків К.Г. - лікар-інтерн дерматовенеролог Вищого державного навчального закладу України "Буковинський державний медичний університет", м. Чернівці

Софроні Ю.В. - лікар-інтерн дерматовенеролог Вищого державного навчального закладу України "Буковинський державний медичний університет", м. Чернівці

\section{Сведения об авторах:}

Гаевская М.Ю. - к. мед. н., доцент кафедры дерматологии и венерологии Высшего государственного учебного заведения Украины "Буковинский государственный медицинский университет", г. Черновцы

Василевич Ю.Я. - врач-интерн дерматовенеролог Высшего государственного учебного заведения Украины "Буковинский государственный медицинский университет", г. Черновцы

Панькив К.Г. - врач-интерн дерматовенеролог Высшего государственного учебного заведения Украины "Буковинский государственный медицинский университет", г. Черновцы

Софрони Ю.В. - врач-интерн дерматовенеролог Высшего государственного учебного заведения Украины "Буковинский государственный медицинский университет", г. Черновцы

\section{Information about the author:}

Gayevska M.Yu. - candidate of Medical Sciences, associated professor of the Department of Dermatology and Venereology of the Higher State Educational Institution of Ukraine "Bukovinian State Medical University", Chernivtsi

Vasylevych Yu.Ya. - resident of dermatovenerology department of the Higher State Educational Institution of Ukraine

"Bukovinian State Medical University", Chernivtsi

Pankiv K.H. - resident of dermatovenerology department of the Higher State Educational Institution of Ukraine "Bukovinian State Medical University", Chernivtsi

Sofroni Yu.V. - resident of dermatovenerology department of the Higher State Educational Institution of Ukraine "Bukovinian State Medical University", Chernivtsi 